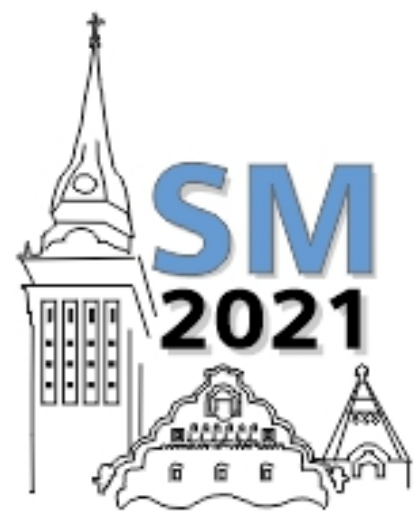

26th International Scientific Conference Strategic Management and Decision Support Systems in Strategic Management

21st May, 2021, Subotica, Republic of Serbia

Agneš Slavić

Faculty of Economics Subotica, University of Novi Sad, Serbia

agnes.slavic@ef.uns.ac.rs

\section{József Poór}

J. Selye University, Komarno, Slovakia

poorj@t-online.hu

\author{
Nemanja Berber \\ Faculty of Economics Subotica, \\ University of Novi Sad, Serbia \\ nemanja.berber@ef.uns.ac.rs
}

Marko Aleksić

Faculty of Economics Subotica, University of

Novi Sad, Serbia

marko.aleksic@ef.uns.ac.rs

\title{
HUMAN RESOURCE MANAGEMENT IN THE TIME OF COVID-19 PANDEMIC: TRENDS AND CHALLENGES
}

\begin{abstract}
The contemporary pandemic of COVID-19 virus is a challenge for each organization in the world. Consequences are wide, and most of them are related to the labor force. Many countries reported a decline in the number of employees as a result of the economic downturn in 2020. Also, organizations all around the world are experiencing other problems with employees like higher level of fear and accompanied stress on workplace, lower employees' productivity, problems in teamwork because of remote working, personal physiological problems of employees due to social distancing, unprepared management teams for this kind of crisis, etc. During the crisis, organizations needed to adapt to the new normal in terms of implementing remote work for greater number of employees, reductions in working hours and even positions, reduction in training and development and compensation budgets, recruitment and career progress freeze, etc. A very sensitive process in this sense is human resource management (HRM), which now has to be re-invented in order to make an adequate response to new issues and challenges. It is important to investigate challenges that are arising in the HRM practice, and new trends that will be important for the future. Since the business is in the recovery phase, but still very harmful, HRM needs to be prepared for the new normal state and in that sense, it is important to be familiar with all potential threats and challenges and to investigate possibilities for overcoming the same. In the previous time, HRM has moved from administrative agent to strategic business partner. Now, it is very important to realize potentials that HRM as a business process has in terms of overcoming the problems that the pandemic brought to business and to investigate the necessity of moving HRM to the new level. The aim of the paper is to present the results of a questionnaire-based research from Hungary of the effects of COVID -19 to HRM practice. The results are very useful for HR managers from other countries from the Central and Eastern European region, to be prepared for this pandemic period and for the post Covid-19 times, too. Keywords: human resource management, COVID-19, new HR practice
\end{abstract}

\section{INTRODUCTION}

The current COVID-19 global health crisis is unprecedented. It is considered to be one of the turning points in history where it is shuffling social and economic norms as we know them and is triggering a new human era. The magnitude and speed of collapse in different activities that have followed are unlike anything experienced in our lifetime (Dirani et al, 2020). According to Carnvale \& Hatak (2020) with the outbreak of COVID-19 pandemic organizations face a grand challenge of unparalleled proportions, one that forces them to dive into and directly manage unprecedented territory as they alter their workforce in technical, physical and socio-psychological ways not seen before.

The COVID-19 pandemic has created a particularly challenging environment for human resource management (HRM) - with managers having to quickly venture into the "unknown unknowns" as they strive to help their workforce adapt to 
and cope with radical changes occurring in the work and social environment (Carnvale \& Hatak, 2020). Butterick \& Charlwood (2020) underline that millions of workers lost their jobs or were placed on government support schemes as businesses and consumers changed their behavior in response to the risks of contracting the virus. Millions more radically changed the ways in which they work, moving from offices to their homes for the same reasons. Further millions faced increased risks of contracting COVID - 19 as a result of their working conditions. The subsequent challenges for those involved in managing people have been huge and efforts to rise to these challenges have often been heroic.

In this period of COVID-19 world pandemic organizations need to find new HR solutions for managing great number of employees working from home, reductions in working hours, reduction in training and development and compensation budgets, recruitment and career progress freeze, etc. The HR policies and practices have to be adapted to the new requirements such as working from home, social distance and supporting employees more than ever to maintain positive contribution and overcome the critical period of COVID-19 pandemic.

The aim of this paper is to show how the COVID-19 pandemic affects the human resource management practice and present the results of two phases of on-line questionnaire-based research from Hungary from year 2020 of the effects of COVID -19 to HRM practice.

\section{THE CHALLENGES OF HUMAN RESOURCE MANAGEMENT IN THE TIME OF COVID-19 PANDEMIC}

The work in $21^{\text {st }}$ century is mainly knowledge-based, offering increased responsibility, better compensation and higher learning opportunities; accelerated work, the demand continues to learn and use newer technologies, and the reduced interaction between people, cause great stress to employees, place higher demands on the well-being of employees and on the health and efficiency of organizations. This is especially true for people working in a knowledge-intensive work environment today (Meri, 2020), where employees are surrounded with learning algorithms, intelligent factories, selfdriving cars and nanotechnology in the workplace (Balog, 2020). Harney \& Collings (2021) stress that even prior to COVID-induced transformations, headline statements on the changing nature of work and employment were commonplace. Megatrends including resurgent nationalism, technological disruption, changing demographics and diversity have dramatic consequences for how people are managed.

Be open-minded and prepared for new challenges are one of the most important competences in the $21^{\text {st }}$ century. Caligiuri et al. (2020) underline that in 2019, Ernst \& Young surveyed 500 board members and chief executive officers (CEOs) globally and found that only $20 \%$ of the executives surveyed believed that their companies were prepared to respond to a large adverse risk. A few short months later, the COVID-19 pandemic crisis arrived proving that their fears were well founded. Concerns related to global supply chain vulnerabilities and financial resilience have come to the fore during the COVID-19 pandemic, along with significant strategic human talent concerns. BCG has called the ongoing COVID-19 pandemic a "people-based crisis.",

The unique nature of COVID-19 pandemic and its effects to economy and the workplaces is well illustrated in the following ,When the financial crisis rocked the business world in 2007-2009, boardrooms turned to corporate finance chiefs. A good CFO could save a company; a bad one might bury it. The COVID-19 pandemic presents a different challenge - and highlights the role of another corporate function, often unfairly dismissed as soft. Never before have more firms needed a hard-headed HR boss. The duties of chief people officers, as human-resources heads are sometimes called, look critical right now. They must keep employees healthy; maintain their morale; oversee a vast remote-working experiment; and, as firms retrench, consider whether, when and how to lay workers off. Their in-trays are bulging." (The Economist, March 24th, 2020).

As an answer for COVID-19 threats, many countries issued 'stay-at-home' orders banning all but essential social and economic activity outside of the household. These orders had an immediate impact on work; unemployment increased; home working increased; some workers were placed on short-time working schemes or were furloughed with government support. There were significant inequalities in who experienced job loss and loss of income compared to continuing to work from home while being paid as normal. The application of HR policies and practices which commodify low skill work has resulted in a deeply unfair distribution of the human suffering arising from the pandemic (Butterick \& Charlwood, 2020).

Cooke, Dickmann \& Parry (2021) underline that while major shocks have happened on a global and country scale the COVID-19 has the potential to substantially change national and international HR approaches and the world of work in general. COVID-19 not only affects the global mobility of the workforce and those working from home, but may also 
present new forms of discrimination and workplace exclusion, such as those related to victims of COVID-19, women with more home responsibilities and the peripheral workforce.

It is obvious that the answer to the COVID-19 crisis is a change in HRM practice, too. HR managers have to find out new ways of managing their workforce and give them support in this period of medical, economic and social crisis. The International Labour Organization (ILO) has defined four pillars concerning the labor standards in these times, presented in Table 1.

Table 1: ILO policy framework: four key pillars in tackling the COVID-19 crisis on the basis of international labor standards.

\begin{tabular}{|l|c|}
\hline Pillar 1 Stimulating the economy and employment & Pillar 2 Supporting enterprises, jobs and incomes \\
- Active fiscal policy & - Extend social protection to all \\
- Accommodative monetary policy & $-\quad$ Implement employment retention measures \\
- Lending and financial support to specific sectors, & - Provide financial/tax and other relief for enterprises \\
\hline including the health sectors & Pillar 4 Relying on social dialogue for solutions \\
\hline Pillar 3 Protecting workers in the workplace & - Strengthen the capacity and resilience of employers' \\
- Strengthen occupational safety and health measures & and workers' organizations \\
- Adapt work arrangements (e.g., teleworking) & - Strengthen the capacity of governments \\
- Prevent discrimination and exclusion & - Strengthen social dialogue, collective \\
- Provide health access for all bargaining and labour & - Expand access to paid leave and processes \\
relations institutions &
\end{tabular}

Source: ILO (2020, p. 12).

The four main activities concerning the labor market in the post Covid-19 period may be the Stimulating the economy and employment; Supporting enterprises, jobs and incomes; Protecting workers in the workplace; and Relying on social dialog for solutions.

The HR managers of all kinds of organizations have to find new ways to manage people in this new era. Multinational companies are facing with challenges due to the fact that national governments had chosen different measures to manage the COVID-19 pandemic. This is why decision-makers in multinational enterprises have undertaken various types of actions to alleviate the impacts of the pandemic. In most cases these actions relate in some way to managing distance and to rethinking boundaries, whether at the macro- or firm-levels (Caligiuri, 2020).

Staffing and it three activities: recruiting, selection and socialization have the aim to find appropriate person for a new position or job vacancy. From March 2020 in the majority of organizations there were new hires. In the period of COVID-19 pandemic, of the global stress and uncertainty, organizations (and especially MNEs) should select for these three critical, cultural agility competencies: tolerance for ambiguity, resilience, and curiosity for all employees working multiculturally. Employees working, even virtually, with clients, vendors, or colleagues from different cultures will now, more than ever, need these competencies to be effective (Caligiuri, 2020).

Training has to contribute to the development of competences of each participant. Maley (2019) underlines that trainings and personnel development programs are also essential during the crisis. Capability development of employees is considered as a strategic option even during turbulence, and its benefits include the potential to adapt to changes and to contribute in an organization's ability to achieve its goals. Vasić (2020) stress that teleworking cannot be successful if no support is provided including regular training and even psychological support in case of burnout and stress. During COVOD-19 pandemic the organizations have to be aware of the characteristics, advantages and disadvantages of different training methods. In this period, training activities have to support the relationship formation as every team member, irrespective of country, is experiencing a similar stressor. The shared stress, anxiety, and frustrations can create ties that further bind already collegial global teams. This shared experience has the potential to enhance cohesion going forward (Caligiuri, 2020). Chanana and Sangetta (2020) underline that many companies are now doing various employee engagement practices in a very innovative and creative manner (virtual team meet-ups, learning and development sessions for new-skill training, digital classrooms training modules, etc.) to keep their employees satisfied and committed. It is very essential to do employee engagement practices during this difficult time.

Reward is a key element of the employment relationship and, in addition to being the single greatest operating cost for many organizations; it has been advocated as a tool for attracting, retaining and motivating employees (Galetić, 2020). In the period of crisis when employees and their families are facing with financial problems, implementing an adequate reward system becomes crucial, too.

During the COVID-19 pandemic, self-directed learning becomes more and more important as there is a lack of professional stimulation while working from home, and it is fostering more self-directed knowledge-seeking to satisfy 
the need to learn, grow, and demonstrate competence. With a growing interest in self-directed learning, companies should actively harness this time to invest in the skill development of employees. At a time when employees' desire to learn, grow, and demonstrate competence is heightened, companies that offer access to, or reimburse, employees' online training achieve a clear win-win; they increase talent capability and, concurrently, foster employee motivation (Caligiuri, 2020).

Internal communication with the employees is usually realized by the help of HR managers. Dirani et al. (2020) state that with the intention of improving situation in a company during the pandemic, HRM should constantly communicate with employees. At the same time, HR managers also should be encouraged and supported by top-management in their efforts during the crisis. As the pandemic is affecting both personal and work lives, people need organizations to keep them informed about safety measures, how the crisis is affecting their jobs, and other things that matter to them. Leaders should be cognizant of the impact that their communication leaves on stakeholders. Therefore, it is critical for the communicated messages to be aligned, realistic, positive, balanced, and sent out via appropriate channels. Moreover, leaders must particularly explain to their stakeholders the crisis resolution strategy and their vision for facing current and future challenges. By being able deliver a concise message that captures the complexity of the crisis and lays out the way ahead, leaders can earn the trust of all stakeholders in the organization and in those leading it. It is important to choose adequate channels for internal communication. Vidaković \& Vidaković (2019) underline that contemporary culture is often characterized as the ,instant culture”, in which new mobile technologies and social nature of Web 2.0 enable individuals' continual access to seemingly unlimited scope of information and media content, no matter where they are. This creates a channel through which these individuals become constantly available for interaction.

Health and safety measures belong to human resource management activities, too. Caligiuri et al (2020) stress that the COVID-19 pandemic has brought health and safety issues to center stage and has placed a spotlight on the role of the HRM function in managing the health and safety of the international workforce. Meri (2020) underlines that healthy work is likely to be the one where the pressures on employees are appropriate based on their abilities and resources, the amount of control they have had over their work, and the support they receive from the people who count them. The COVID-19 pandemic has pushed a massive number of employees, who were already facing stress from the health risk itself, to working from home. The COVID-19 pandemic has produced tremendous novelty and uncertainty which is affecting the mental health of many people around the world (World Health Organization, 2020). Even as the health risks of the pandemic begin to wane in some countries and the probability of a vaccine appears high, the novel ways of working remotely and the fears around the global recession will continue to produce a state of uncertainty.

Before the COVID-19 era remote work, home-office, flextime and other alternative work arrangements were confirmed to contribute to employee satisfaction and the flexibility of organizations. During the COVID-19 era the home-office arrangements has further limited the segmentation between work and private spheres leading to greater difficulties in "unplugging" from work demands. The closure of schools and child-care services has increased parental demands for employees, further blurring the lines between work and family spheres. On the other hand, the grand challenge of our current health crisis is likely to illuminate vulnerabilities in an increasingly relevant, yet understudied, segment of contemporary family structure: childless and single employees, as they may be at greatest risk of loneliness, a felt lack of purpose, and associated negative effects on well-being (Carnvale \& Hatak, 2020).

During the period of crisis, leadership become crucial. Dirani et al. (2020) underline that in the period of pandemic organizational leaders have to rely more on their instincts and insights, provided by human resource professionals, to ensure their organization and employees feel supported. Organizations that want to survive crisis situations must develop the necessary infrastructure that gives space to healthy communication, interactive decision making, and strategic planning in a flexible atmosphere that is agile and open to growth. By embedding flexibility in their culture, organizations can better understand the core issues of employees and, eventually, respond efficiently to arising challenges by taking appropriate strategic decisions. Dirani et al (2020) state that during this pandemic, organizations will flourish under a leader who a) provides strong roles and purpose; b) shares leadership; c) communicates; d) ensures employee's access to technology; e) prioritizes employee's emotional stability; f) maintains organizational financial health; and g) promotes organizational resilience.

Collings et al. (2021) highlight the central role that HR and strategic HRM have during the COVID-19 pandemic. They claim that in this period it is important to analyze how work context influences employee behaviors and actions; the tensions among stakeholders; and the tensions between the strategic and operational roles of HR.

\section{THE EFFECT OF COVID-19 PANDEMIC OF HRM ACTIVITIES IN HUNGARY}

In 2020 an academic research team obtained an on-line questionnaire-based research on the effects of COVID-19 pandemic on the human resource management activities in Hungary in two phases. 
The first phase of the research was realized in June-July 2020 with 508 responding organizations, while the second took place in May-November 2020 with 1041 responding organizations. Both in the first and second phase the majority of respondents came from private-owned companies (about half of the sample), about one quarter of the respondents were from foreign-owned companies, while about $15 \%$ of the sample came from public sector. In the first phase $72,1 \%$ of analyzed organizations belonged to SME sector, while in the second phase about $63,6 \%$. The majority of the respondents in both research periods were from industry, not from service-sector. And 8 percent of responding organizations belonged to the hotel and hospitality industry.

The table 2 presents if the organizations had action for pandemic situation.

Table 2: Organizations possessing an action plan for pandemic situation

\begin{tabular}{|l|c|c|}
\hline & $\mathbf{1}^{\text {st }}$ phase (\%) & $\mathbf{2}^{\text {nd }}$ phase (\%) \\
\hline We had it before the pandemic and use it without changes & 2,4 & 10,6 \\
\hline We had it before the pandemic but we had to change it & 11,8 & 16,6 \\
\hline We did not have it, but had to prepare it because of the pandemic & 54,2 & 55,8 \\
\hline We do not have, but plan to prepare it & 9,7 & 7,8 \\
\hline We do not have it and think that there is no need for it & 21,9 & 9,2 \\
\hline
\end{tabular}

Source: Poór et al., 2021, p. 20.

In the second phase of the research only $9 \%$ of the organizations considered that they do not need an action plan for pandemic situation.

In the first phase the majority $(57,5 \%)$ of respondents stated that they had prepared their own action plan for pandemic situation, while in $19,1 \%$ the corporate headquarters/the owner had prepared it. In the second phase $46 \%$ of the respondents claimed that they have prepared their own action plan, while in $43,0 \%$ the headquarters /the owner had prepared it. It shows that in the second half of year 2020 almost all MNC headquarters and owners had prepared their action plans and outlines the subsidiaries had to follow.

The table 3 shows the data on the headcount changes in the first and second phase of the research.

Table 3: The changes in the headcount in the first and second research period

\begin{tabular}{|c|c|c|}
\hline 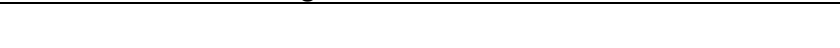 & 1st phase (\%) & $2^{\text {nd }}$ phase (\%) \\
\hline Significant decline & 9,4 & 6,4 \\
\hline Decline & 22,8 & 20,9 \\
\hline Not changed & 62,3 & 56,6 \\
\hline Increased & 4,2 & 10,5 \\
\hline Total & 100,0 & 100,0 \\
\hline
\end{tabular}

Source: Poór et al., 2021, p. 27.

As the data show the majority of interviewed organizations tried to survive the pandemic period without significant layoffs. In the course of the research, we also found that many companies re-employed some of the workers made redundant during the first wave after it passed.

The next table presents the external factors of the crisis and their significance for the organizations in Hungary in 2020.

Table 4: The external factors of the crisis which have significant effect on the organizations

\begin{tabular}{|l|c|c|}
\hline & $\mathbf{1}^{\text {st }}$ phase (\%) & $\mathbf{2}^{\text {nd }}$ phase (\%) \\
\hline The decline of the domestic demand & 30,6 & 15,9 \\
\hline The decline of foreign demand & 22,9 & 12,1 \\
\hline The introduction of curfew measure & 37,5 & 24,5 \\
\hline The break of supply chain & 11,6 & 7,9 \\
\hline
\end{tabular}

Source: Poór et al., 2021, p. 28.

Based on the research data it may be concluded that the organizations succeeded to adapt to the most significant external factors of the pandemic period.

According to the interviewed organizations the most important challenges for the employees in the first research period were: the increased family requirements, work-family conflict, the significant decline in family incomes, they had to use their yearly holidays, the job requirements had increased, etc. In the second research period the employees' challenges 
were: increased family requirements, work-family conflict, they had to use their yearly holidays, the health risks increased.

The next table presents the data on how the organizations reacted to the COVID-19 pandemic, which measures they took as an answer to the crisis.

Table 5: The organizations general answers to the COVID-19 crisis - the most characteristic measures

\begin{tabular}{|l|c|c|}
\hline & $\mathbf{1}^{\text {st }}$ phase (\%) & $\mathbf{2}^{\text {nd }}$ phase (\%) \\
\hline Postponing purchases & 28,3 & 13,4 \\
\hline General reduction of expenditures & 27,9 & 17,7 \\
\hline Strategy revision & 22,7 & 21,9 \\
\hline Communication development & 23,0 & 16,2 \\
\hline Increased organizational efficiency & 20,5 & 20,5 \\
\hline Lay off strategic investments & 18,9 & 7,8 \\
\hline
\end{tabular}

Source: Poór et al., 2021, p. 34-35.

In the first research period (May-June of 2020) the organizations implemented radical measures to adapt to the pandemic crisis. In the second phase the organizations used fewer radical measures, as they have understood that the crisis will last longer and they have to adapt to it using soft measures.

The table 6 presents the HR actions as crises-management actions in the first and second research period.

Table 6: The HR actions as COVID crisis management actions - the most characteristic measures

\begin{tabular}{|l|c|c|}
\hline & $\mathbf{1}^{\text {st }}$ phase (\%) & $2^{\text {nd }}$ phase (\%) \\
\hline Disposing/allowing working from home & 53,0 & 37,1 \\
\hline New occupational health and safety measures & 42,2 & 40,6 \\
\hline Stopping new hires & 29,7 & 18,3 \\
\hline Wage freeze & 20,2 & 6,8 \\
\hline Helping the employees in their social problems & 18,1 & 13,4 \\
\hline The reduction of working hours & 15,0 & 9,9 \\
\hline Helping the employees in their self-development & 14,1 & 10,6 \\
\hline
\end{tabular}

Based on the research results the most characteristic HR measures in the first half of 2020 in Hungary were the disposing/allowing working from home, new occupational health and safety measures, stopping new hires and wage freeze. In the second half of 2020 the implementation of new occupational health and safety measures and the dispose/allow working from home were the most characteristic HR measures.

The researchers were interested in HR fields which will be more important due to the COVID-19 pandemic. The next table presents the obtained data.

Table 7: The HR fields becoming more important due to COVID-19 pandemic

\begin{tabular}{|l|c|c|}
\hline & $\mathbf{1}^{\text {st }}$ phase (\%) & $\mathbf{2}^{\text {nd }}$ phase (\%) \\
\hline Internal communication & 56,3 & 55,5 \\
\hline Atypical employment & 53,6 & 44,6 \\
\hline Occupational safety & 35,7 & 47,3 \\
\hline Headcount planning & 31,6 & 31,7 \\
\hline Job analysis and design & 30,8 & 35,0 \\
\hline Retention management & 28,0 & 28,7 \\
\hline Performance management & 24,7 & 23,0 \\
\hline
\end{tabular}

Source: Poór et al., 2021, p. 50.

In the first research period the HR mangers from Hungary considered internal communication and atypical employment to be the most important HR fields due to the COVID-19 pandemic. In the second research period the HR fields becoming more important are considered to be: internal communication and job safety.

In table 8 we are presenting the HR fields to be changed due to the COVID-19 pandemic based on the opinion of HR managers in the first and second research period.

Table 8: The HR fields to be changed due to COVID-19 pandemic 


\begin{tabular}{|l|c|c|}
\hline & 1st $^{\text {phase }} \mathbf{( \% )}$ & 2 $^{\text {nd }}$ phase (\%) \\
\hline Internal communication & 46,7 & 50,4 \\
\hline Administration & 30,2 & 27,5 \\
\hline Training & 27,7 & 31,5 \\
\hline Compensation & 26,6 & 32,8 \\
\hline Employment & 23,6 & 27,9 \\
\hline
\end{tabular}

Source: Poór et al., 2021, p. 51.

In the first research period the majority of interviewed HR managers considered that internal communication and HR administration are the fields which have to be changed the most significantly due to the pandemic. In the second research period they contemplated internal communications to be changed, too, but the second field was compensation.

Not only the HR activities have to be changed due to the pandemic, but the employees' competences, too. In the last table we are presenting the analyzed organizations opinion about the employees' most important competences due to the pandemic.

Table 9: The most important competences of employees due to pandemic

\begin{tabular}{|l|c|}
\hline \multicolumn{1}{|c|}{$\mathbf{1}^{\text {st }}$ phase (\%) } & $2^{\text {nd }}$ phase (\%) \\
\hline Digital competences, IT skills & communicational skills \\
\hline Communication skills & flexibility, quick adaptation \\
\hline Empathy, EQ, social skills & empathy, EQ, social skills \\
\hline Cooperation, team-work & digital competences, IT skills \\
\hline Flexibility, quick adaptation & cooperation, team-work \\
\hline
\end{tabular}

Source: Poór et al., 2021, p. 54.

It is interesting that in the first research period the Hungarian organizations considered their employees' digital competences and IT skills as the most important competences, while in the second research period the communicational skills were the most important competence.

Based on the obtained research results of the first and second research phase it can be concluded that the majority of organizations in Hungary did not have action plan for pandemic, they had not changed the headcount, and at organizational level they implemented strategy revision and measures for increasing efficacy. The strategic importance of HR activities has increased, the most characteristics HR measures were the disposing/allowing working from home and introducing new occupational safety measures. It is considered that internal communication, occupational safety and atypical working arrangements are the HR fields which will become more important due to the pandemic. Internal communication and compensation will be the most important HR activities due to the COVID-19 crisis. The main important competences of employees Hungarian organizations are expecting from their employees are: communicational skills, flexibility and empathy and social skills.

\section{CONCLUSIONS}

The individuals, organizations and states were not prepared for the current health crisis caused by COVID-19 pandemic. The majority of organizations needed to adapt to new rules at workplaces, to allow remote work for greater number of employees, introduce reductions in working hours and even positions, reduction in training and development and compensation budgets, recruitment and career progress freeze, etc.

Human resource management had to give answers to the challenges of this global health crisis regarding employees, their safety, performances, boarder family requirements and stress they are facing with for months. In this period of global crisis HR managers have to implement new HR measures to ensure the company survival and the physical and mental health of employees. Concerning staffing there is a need for risk-taking, open-minded employees with social skills, who are ready for self-directed and cross-cultural training. Internal communication becomes one of the most important $\mathrm{HR}$ activities, alike introducing new occupational safety measures.

The research results from Hungary from 2020 point out that organizations are facing similar problems, as their counterparts world-wide, HRM become more important in the crisis management process, especially internal communications, atypical employment and occupational safety measures. Besides, internal communications and compensation systems are the HR fields which have to be changed the most due to the pandemic, in order to give adequate answers to the present requirements. 
By our opinion, it is important that HR managers, company leaders and decision makers at national levels do not just pay attention to the negative effects of the COVID-19 pandemic, but try to find out new and forward-looking measures which can be successfully implemented in the post COVID-19 period, too.

\section{REFERENCES}

Balog, K. (2020). The concept and competitiveness of agile organization in the fourth industrial revolution's drift. Strategic Management, 25(3), 14-27.

Butterick, M., \& Charlwood, A. (2021). HRM and the COVID-19 pandemic: How can we stop making a bad situation worse?. Human Resource Management Journal.

Caligiuri, P., De Cieri, H., Minbaeva, D., Verbeke, A., \& Zimmermann, A. (2020). International HRM insights for navigating the COVID-19 pandemic: Implications for future research and practice.

Chanana, N. \& Sangetta. (2020). Employee engagement practices during COVID-19 lockdown. Journal of Public Affairs, e2508.

Carnevale, J. B., \& Hatak, I. (2020). Employee adjustment and well-being in the era of COVID-19: Implications for human resource management. Journal of Business Research, 116, 183-187.

Collings, D. G., McMackin, J., Nyberg, A. J., \& Wright, P. M. (2021). Strategic human resource management and COVID-19: Emerging challenges and research opportunities. Journal of Management Studies.

Cooke, F. L., Dickmann, M., \& Parry, E. (2020). IJHRM after 30 years: taking stock in times of COVID-19 and looking towards the future of HR research. The International Journal of Human Resource Management, 1-23.

Dirani, K. M., Abadi, M., Alizadeh, A., Barhate, B., Garza, R. C., Gunasekara, N., ... \& Majzun, Z. (2020). Leadership competencies and the essential role of human resource development in times of crisis: a response to Covid-19 pandemic. Human Resource Development International, 23(4), 380-39.

Galetić, L. (2020). Reward strategy and practice as a tool to retain employees: case of Croatia. Strategic Management, 25(3), 3-13.

Harney, B., \& Collings, D. G. (2021). Navigating the shifting landscapes of HRM. Human Resource Management Review, 100824.

International Labour Organization. (2020). ILO Monitor: COVID-19 and the World of Work.

Maley, J. F. (2019). Preserving employee capabilities in economic turbulence. Human Resource Management Journal, 29(2), 147-161.

Meri, M. (2020). New Trends in HRM \& Knowledge Management in the Health Sector beyond COVID-19-A Practical Model. Business Excellence and Management, 10(SI 1), 5-21.

Poór, J., Dajnoki, K., Pató Gáborné Szűcs, B., \& Szabó Sz. (Eds.) (2021): Koronavírus-válság kihivásai és HR válaszok - Első és második fázis összehasonlitása. Gödöllö: Magyar Agrár- és Élettudományi Egyetem.

The coronavirus crisis thrusts corporate HR chiefs into the spotlight. (March 24th, 2020). The Economist.

Vasic, M. (2020). Challenges of teleworking during the Covid-19 pandemic. Anali Ekonomskog Fakulteta $U$ Subotici, 56(44), 63-79.

Vidaković, M., \& Vidaković, D. (2019). Digital media, creativity, and marketing, within the scope of the contemporary instant culture. Anali Ekonomskog fakulteta u Subotici, (41), 131-144.

World Health Organization. (2020). Physical and mental health key to resilience during COVID-19 pandemic 